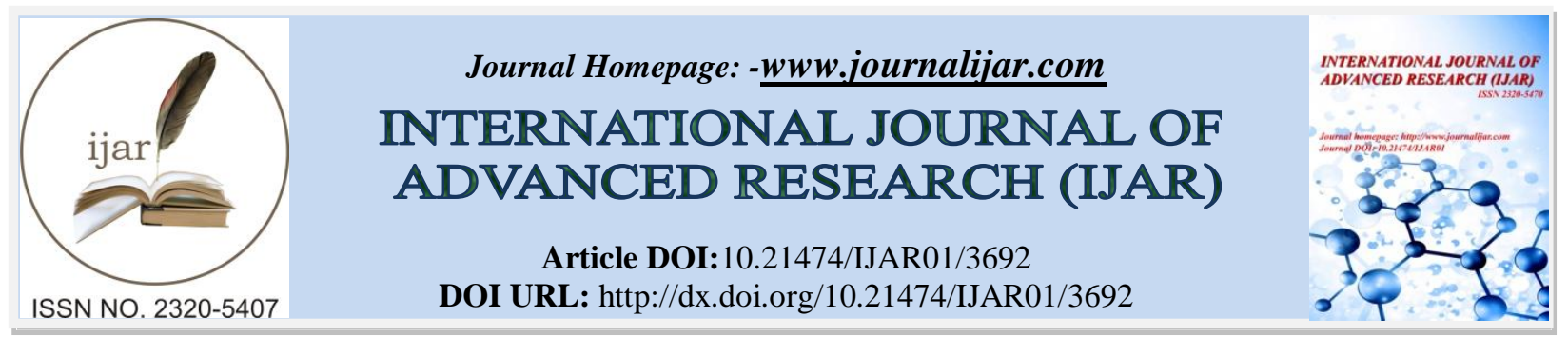

RESEARCH ARTICLE

\title{
LOW SERUM VITAMIN D LEVELS IN EGYPTIAN ADULTS WITH CHRONIC PRIMARY IMMUNE THROMBOCYTOPENIA: A SINGLE CENTER STUDY.
}

\section{Abdel Rahman A Soliman, M.D ${ }^{1}$, Walaa A Elsalakawy M.D ${ }^{1}$, Alia M Saeed M.D ${ }^{1}$ and Sana A Mohammed M.B., B. $\mathbf{C H}^{2}$.}

1. Clinical Hematology and Bone Marrow Transplant Unit, Internal medicine department, Faculty of Medicine Ain Shams University, Cairo, Egypt.

2. Faculty of medicine- MisurataUniveristy, Misurata, Libya.

\section{Manuscript Info}

[..........................

Manuscript History

Received: 13 January 2017

Final Accepted: 08 February 2017

Published: March 2017

Key words:-

ITP, 25(OH) D, vitamin D

\section{Abstract}

Objectives: Immune thrombocytopenia (ITP) is a disorder characterized by immune-mediated accelerated platelet destruction and suppressed platelet production. Low vitamin D levels have been found in several autoimmune diseases, such as rheumatoid arthritis, SLE. The mechanisms underlying the link between vitamin D with autoimmunity are not completely understood. No currently available studies about vitamin D status in primary ITP patients.

Aim: To evaluate vitamin D levels in patients with primary chronic ITP and compare these levels with normal control subjects and patients with thrombocytopenia due to other non-immune causes Methods: The study included 80 adult subjects, 40 ITP patients (They were segregated into 20 responders and 20 non-responders), 20 cases of thrombocytopenia due to non ITP causes and 20 healthy control subjects. Measurement of serum 25monohydroxyvitamin D was done with ELISA.

Results: Vitamin D levels were significantly lower in patients with ITP (range $=2-40 \mathrm{ng} / \mathrm{ml} ; \quad$ mean $\pm \mathrm{SD}=17.29 \pm 10.96 \quad \mathrm{ng} / \mathrm{ml}$ ) and thrombocytopenia due to non-ITP causes (range $=10-40 \mathrm{ng} / \mathrm{ml}$; mean $\pm \mathrm{SD}=21.05 \pm 8.31 \mathrm{ng} / \mathrm{ml}$ ) in comparison to normal healthy controls $($ range $=10-65 \mathrm{ng} / \mathrm{ml}$; mean $\pm \mathrm{SD}=36.70 \pm 16.30 \mathrm{ng} / \mathrm{ml}) \quad(\mathrm{P}=0.000)$, but there was no statistically significant difference between levels in ITP versus non- ITP thrombocytopenia $(\mathrm{P}=0.225)$. There was no statistical significant difference between responders \& non-responders Conclusions: Vitamin D levels are lower among chronic ITP patients in relation to healthy control subjects which might point out to a role in aetiopathogenesis of ITP attributable to vitamin D deficiency.

Copy Right, IJAR, 2017,. All rights reserved.

\section{Introduction:-}

Immune thrombocytopenia (ITP) is a disorder characterized by immune-mediated accelerated platelet destruction and suppressed platelet production ${ }^{[1]}$

Corresponding Author:-Walaa A Elsalakawy. Address:-Clinical Hematology and Bone Marrow Transplant Unit, Internal medicine department , Faculty of Medicine - Ain Shams University, Abbasiya, Cairo, Egypt. 
In patients with ITP, antiplatelet auto-antibodies frequently appear to be directed against GpIb/IX and GPIIb/IIIa expressed on platelets and megakaryocytes ${ }^{[2]}$

Abnormalities of cell-mediated immunity are known to contribute to the pathologic process. Like many other autoimmune diseases, ITP has a T helper cell type 1 bias and a reduced activity of T-regulatory cell ${ }^{[2]}$

Vitamin D, a steroid hormone, which is known to play an essential role in calcium homeostasis, but since the receptor for vitamin D (VDR) is found in cells in almost every tissue, and the enzyme 1- $\alpha$ hydroxylase necessary for the final activation of vitamin $\mathrm{D}$ also has a widespread distribution, it appears obvious that vitamin $\mathrm{D}$ must have a multitude of function ${ }^{[3]}$

Lower vitamin D levels have been found in several autoimmune diseases, such as rheumatoid arthritis, systemic lupus erythematosus, systemic sclerosis, type 1 diabetes mellitus, multiple sclerosis, inflammatory bowel diseases, and, autoimmune gastritis ${ }^{[4]}$

The mechanisms underlying the link between vitamin D with autoimmunity are not completely understood, but probably are associated with its anti-inflammatory and immunomodulatory functions ${ }^{[5]}$

Several studies confirm that vitamin D enhances the innate immune response, whereas it exercises an inhibitory action on the adaptive immune system by inhibiting the proliferation of type 1T helper cells, increasing the quantity of type $2 \mathrm{~T}$ helper cells, increasing the quantity of $\mathrm{CD} 4+/ \mathrm{CD} 25+\mathrm{T}$-regulator cells, inhibiting B cell proliferation, generation of B memory cells, plasma cell differentiation and immunoglobulin production ${ }^{[6]}$

No currently available studies about vitamin D status in primary ITP patients.

\section{SUBJECTS AND METHODS:-}

\section{Subjects:-}

The current case-control study was conducted on 80 adult subjects (age $\geq 18$ years) including 40 ITP patients, 20 patients with thrombocytopenia secondary to other non-immune diseases, and 20 healthy control subjects. All patients were recruited from the Clinical Hematology Unit, Internal Medicine Department, Faculty of Medicine, AinShams University, Cairo, Egypt.

An informed consent was taken from all subjects participating in the present study according to declaration of Helsinki.

The subjects enrolled in this study were divided into the following groups:-

- Group-I: Included 40 adult patients diagnosed as having chronic primary ITP who met the diagnostic criteria of

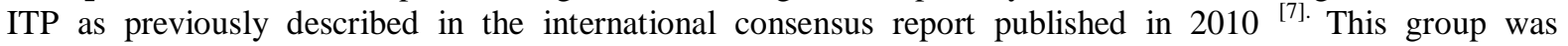
subdivided into:

$>$ Group-Ia: Included 20 patients who were responders to treatment.

$>$ Group-Ib: Included 20 non-responder ITP patients.

- Group-II: Included 20 patients with secondary thrombocytopenia. This group included: 8 patients with acute myeloid leukemia (AML), 5 patients with myelodysplastic syndrome (MDS), and 7 patients with aplastic anemia. All the patients with the above diseases were undertreatment.

- Group-III: Included 20 sex and age matched healthy controls subjects with normal platelet count and no concurrent illnesses or medications at the time of blood withdrawal.

\section{Inclusion criteria:-}

- Adult (age $\geq 18$ years).

- Primary chronic ITP.

- ITP patients who received the first line treatment by steroid therapy.

Exclusion criteria:-

- Age $<18$ years.

- Secondary ITP.

- ITP patients on second line therapy like azathioprine or TPOs

- Chronic renal disease. 
- Chronic liver disease.

- Malnutrition and malabsorption.

\section{Plan of treatment in ITP patients:-}

Patients were treated by the first line steroid therapy (i.e. prednisolone $1 \mathrm{mg} / \mathrm{kg}$ ) for 3-4 weeks followed by tapering. Patients on second line therapy (e.g. Azathioprine, TPO and danazol, ...etc.) were excluded from this study, and the patients were subdivided into responders and non-responders.

\section{Definition of response:-}

Patients were considered responders if they have platelet count between 30 and $100 \times 10^{9} / 1$, doubling of the baseline platelet count and no clinically overt bleeding ${ }^{[7]}$.

While patients were considered resistant "Non-responders" if they have any platelet count lower than $30 \times 10^{9} / 1$ or less than doubling of the baseline count, active bleeding, or steroid dependence ${ }^{[7]}$.

\section{Methods:-}

Assessment of serum level of $25(\mathrm{OH}) \mathrm{D}$ :-

\section{Sample collection:-}

For each subject, about $5 \mathrm{ml}$ of venous blood was drawn under complete aseptic conditions and dispensed into a labeled vacutainer containing gel and clot activator, and serum was separated by centrifugation for 5 minutes, then stored at temperature $-20^{\circ} \mathrm{C}$ till assay for measurement of $25(\mathrm{OH})$ vitamin D was done by ELISA assay using a commercially available ELISA kit (Calbiotech, A Life Science company). The values were expressed in ng/ml.

\section{Definition of vitamin D deficiency:-}

Vitamin D deficiency is defined as a $25(\mathrm{OH})$ D level of $20 \mathrm{ng} / \mathrm{ml}$ or less, vitamin D insufficiency as 21 to $29 \mathrm{ng} / \mathrm{ml}$, and vitamin D sufficiency as $30 \mathrm{ng} / \mathrm{ml}$ or greater. ${ }^{[8]}$

\section{Statistical analysis:-}

Data were collected, revised, coded and entered to the Statistical Package for Social Science (IBM SPSS) version 20. Qualitative data were presented as number and percentages while quantitative data were presented as mean, standard deviations and ranges when parametric and median with interquartile ranges (IQR) when non parametric.

The p-value was considered significant as the following:

$P>0.05$ : Non significant

$\mathrm{P}<0.05$ : Significant

$\mathrm{P}<0.01$ : Highly significant.

\section{RESULTS:-}

\section{Demographic data and disease characteristics}

Subjects enrolled into the study were 80 adult subjects, they were divided into 40 chronic ITP patients (equally subdivided into responders and non-responders), they were 36 females and 4 males with a female: male ratio of 9:1 with mean age \pm SD of $33.41 \pm 9.67$ years ranging from 18-50 years, 20 cases of thrombocytopenia due to other reasons with 16 females $(80 \%)$ and 4 males $(20 \%)$ with mean age \pm SD of $36.70 \pm 13.30$ years ranging from $19-60$ years, and 20 adults apparently healthy control subjects , 17 females and 3 males with age range of $18-44$ years and mean \pm SD of $29.90 \pm 8.07$ years.

The three groups were matched as regards age $(\mathrm{P}=0.123)$ and $\operatorname{sex}(\mathrm{P}=0.560)$.

Demographic data and disease characteristics amongst the 3 studied groups are illustrated in table number (1).

Hemoglobin levels across the studied groups

Hemoglobin levels were significantly lower in patients with thrombocytopenia due to other (non-ITP) causes $($ mean $\pm \mathrm{SD}=7.80 \pm 1.03 \mathrm{~g} / \mathrm{dl})$ than ITP patients $($ mean $\pm \mathrm{SD}=11.31 \pm 1.48 \mathrm{~g} / \mathrm{dl})(\mathrm{P}=0.000)$ or healthy normal controls $($ mean $\pm \mathrm{SD}=12.66 \pm 1.37 \mathrm{~g} / \mathrm{dl})(\mathrm{P}=0.000)$. 


\section{Platelet counts across the studied groups}

As regards platelet counts, they were significantly reduced in ITP patients and patients with thrombocytopenia due to other causes as compared to healthy controls $(\mathrm{P}=0.000)$.

The mean platelet volumes were significantly higher in ITP patients (mean $\pm \mathrm{SD}=11.16 \pm 2.14 \mathrm{fl}$ ) than patients with thrombocytopenia due to non-ITP patients (mean $\pm \mathrm{SD}=9.10 \pm 3.40 \mathrm{fl}$ ) and healthy controls (mean $\pm \mathrm{SD}=9.79 \pm 1.01 \mathrm{fl}$ ) $(\mathrm{P}=0.004)$.

Vitamin D levels across the studied groups:-

25 monohydroxyvitamin D levels were significantly lower in patients with ITP(range $=2-40 \mathrm{ng} / \mathrm{ml}$; mean \pm $\mathrm{SD}=17.29 \pm 10.96 \mathrm{ng} / \mathrm{ml}$ ) and thrombocytopenia due to non-ITP causes (range $=10-40 \mathrm{ng} / \mathrm{ml} ;$ mean $\pm \mathrm{SD}=21.05 \pm 8.31$ $\mathrm{ng} / \mathrm{ml}$ ) in comparison to normal healthy controls (range $=10-65 \mathrm{ng} / \mathrm{ml}$; mean $\pm \mathrm{SD}=36.70 \pm 16.30 \mathrm{ng} / \mathrm{ml})(\mathrm{P}=0.000)$, but there was no statistically significant difference between levels in ITP versus non- ITP thrombocytopenia $(\mathrm{P}=0.225)$, this is well illustrated in figure (1) attached to the appendix.

Calculating the degree of deficiency of vitamin D in the 3 groups, it was found that $27(67.5 \%)$ of the ITP patients were deficient in vitamin D; with recording values $\leq 20 \mathrm{ng} / \mathrm{ml}$. Of those 27 patients, 15 patients are severely deficient (ie $\leq 10 \mathrm{ng} / \mathrm{ml})$. Other 6 ITP patients $(15 \%)$ were insufficient and only 7 of them $(17.5 \%)$ were having sufficient values of vitamin $\mathrm{D}$.

When these data are compared to healthy normal controls, we observed that only 4 (20\%) of them were deficient, 1 of them had severe deficiency. Other 4 were insufficient while $12(60 \%)$ had normal levels.

In thrombocytopenia due to non-ITP causes, half of them were deficient (10) while 5 (25\%) were insufficient. And 5 only (25\% had normal values).

\section{Vitamin D levels in ITP patients in relationship to response:-}

When further segregating ITP patients into responders and non-responders; we found that at enrollment time, the platelet count was significantly lower among non-responders (median $=64.5 \times 10^{9} / \mathrm{L}$ ) than responders (median $\left.=200.5 \times 10^{9} / \mathrm{L}\right)$ with highly significant $\mathrm{P}$ value $(\mathrm{P}=0.000)$. At the same time there was no significant difference in hemoglobin level between non responders and responders $($ mean $\pm \mathrm{SD}=11.18 \pm 1.63 \mathrm{~g} / \mathrm{dl}$ versus $10.65 \pm 1.56 \mathrm{~g} / \mathrm{dl}$ respectively) $(\mathrm{P}=0.296)$.

The two subgroups (non-responders and responders) showed no statistical significant difference as regards vitamin $\mathrm{D}$ levels being as following $(\mathrm{mean} \pm \mathrm{SD}=15.73 \pm 10.00 \mathrm{ng} / \mathrm{ml}$ in responders in relation to mean $\pm \mathrm{SD}=18.85 \pm 11.89$ $\mathrm{ng} / \mathrm{ml}$ in non-responders with a P-value of 0.374).

25(OH) D levels when correlated to age, disease duration, dose of steroids given and platelet counts in ITP patients, they showed no significant correlation.

\section{DISCUSSION:-}

Immune thrombocytopenia (ITP) is an autoimmune disorder characterized by accelerated platelet destruction and suppression of platelet production, resulting in low platelet count ${ }^{[9]}$

Vitamin D is recognized as a true steroid hormone that exerts several biological activities, including regulation of the immune system. So, its deficiency can contribute to the pathophysiological mechanisms for the development of autoimmune diseases ${ }^{[10]}$

The aim of this study is to assess vitamin D status in adult patients with primary immune thrombocytopenia (ITP) and to correlate it with response to first line treatment (steroid therapy).

The present study included forty chronic ITP patients (36 females and 4 males), twenty patients with thrombocytopenia secondary to other non- immune diseases ( 16 females and 4 males), and twenty normal healthy subjects (17 females and 3 males). There were no statistically significant differences between the three groups as regards sex and age (with $\mathrm{p}$ values= 0.560 and 0.123 respectively). 
In this study, $90 \%$ of the ITP patients were females and only $10 \%$ were males with female to male ratio 9:1, which reflects a higher incidence of ITP in females. This observation is consistent with the results of Schoonen et al. ${ }^{[11]}$ who found that the incidence of ITP was statistically significantly higher in women compared to men. And also Saeidi et al. ${ }^{[12]}$ who found that the ITP prevalence was higher in females those aged above 16 compared to males of the same age with ratio 7: 3. As an autoimmune disease; ITP is expected to have higher incidence in females.

The mean age of ITP patients in our study was $33.41 \pm 9.67$ years, this was same as that described by Cines and Bussel $^{[13]}$ who stated that the incidence of ITP is more common in women aged between 18 and 40years. On the other hand, Neylon et al. ${ }^{[14]}$ estimated a higher incidence of ITP among those aged 60 years and older.

The platelet count in ITP patients (median of $114 \times 10^{9} / \mathrm{L}$ ) and in the patients with thrombocytopenia due to non-ITP causes (median of $36.5 \times 10^{9} / \mathrm{L}$ ) were significantly decreased in comparison to healthy controls $\left(296 \times 10^{9} / \mathrm{L}\right)$ $(\mathrm{p}<0.001)$. On the other hand, the haemoglobin levels were significantly lower in patients with thrombocytopenia due to non-ITP causes (mean $\pm \mathrm{SD}=7.80 \pm 1.03$ ) than in normal healthy controls (mean $\pm \mathrm{SD}=12.66 \pm 1.37$ ) and ITP patients (mean $\pm \mathrm{SD}=11.31 \pm 1.48$ ) with $\mathrm{p}$ value $=0.000$, this finding was due to the nature of the diseases included in this group of patients (AML, aplastic anaemia, and MDS) that are characterized by the manifestations of bone marrow failure. The ITP patients show mean haemoglobin level around the normal because it is the disease of isolated thrombocytopenia.

In this study; we observed that the mean platelet volumes (MPV) were significantly higher in patients with ITP (mean $\pm \mathrm{SD}=11.16 \pm 2.14 \mathrm{fl}$ ) than that in patients with thrombocytopenia due to non-ITP causes (hypoproductive thrombocytopenia) (mean $\pm \mathrm{SD}=9.10 \pm 3.40 \mathrm{fl}$ ) and in normal controls (mean $\pm \mathrm{SD}=9.79 \pm 1.01 \mathrm{fl}$ ) with $\mathrm{p}$ value 0.002 and 0.035 respectively. This result agrees with the finding reported by Ntaios et al. ${ }^{[15]}$;Negash et al. ${ }^{[16]}$ who found that the MPV is significantly elevated in ITP patients than in patients with hypoproductive thrombocytopenia. In disagreement with this result, a study conducted by Borkataky et al. ${ }^{[17]}$ who found no significant difference in the MPV between the destructive thrombocytopenia groups and the control group. However, larger platelets have more granules, aggregate more rapidly with collagen, have a higher thromboxane A2 level, and express more glycoprotein $\mathrm{Ib}$ and IIb/IIIa receptors than smaller platelets, which may explain the lower bleeding tendency in ITP patients ${ }^{[18] .}$

Results in the present study revealed non-significantdifference in serum $25(\mathrm{OH}) \mathrm{D}$ levels among ITP femalesand malespatients. In concordance to our results, study by Elsammak et al ${ }^{[19]}$ whoevaluated the vitamin D status of a cohort of healthy young Saudi Arabians in the Eastern region of Saudi Arabia. A sample of 139 blood donors studied. They found that serum $25(\mathrm{OH}) \mathrm{D}$ levels did not differ significantly between males and females. And this result is consistent with the findings of Amital et al. ${ }^{[20]}$ who conducted their study on SLE patients from several European and Israeli cohorts and found that vitamin D level did not differ by gender. However the results of this present study did not agree with the results of a study by Wright et al. ${ }^{[21]}$ conducted on SLE patients who found that female sex was a predictor for vitamin D deficiency. To our knowledge; no similar studies were conducted on ITP patients before.

In the present study, we did not find a significant correlation between vitamin $\mathrm{D}$ levels and age or disease duration in ITP patients. This finding is in line with the results of a study by Emam et al. ${ }^{[22]}$ who studied a comparable number of Egyptian SLE patients (40 SLE patients and 20 age and sex matched controls) and did not find significant correlation between vitamin D level and age or disease duration. And another study by Rossini et al. ${ }^{[23]}$ conducted on rheumatoid arthritis patients did not find an association between vitamin D level and disease duration. Also Dias de Castro et al. ${ }^{[24]}$ in their study on patients with Inflammatory Bowel Disease found no correlation between vitamin $\mathrm{D}$ and age or disease duration. However, Karatay et al. ${ }^{[25]}$ studied 32 patients with Behcet's disease and found that age was one of the predictors of $25(\mathrm{OH}) \mathrm{D}$ levels.

In the present study, we have found significantly lower mean 25(OH)D levels among ITP cases compared to healthy control group, $(17.29 \pm 10.96 \mathrm{ng} / \mathrm{ml})$ vs $(36.70 \pm 16.30 \mathrm{ng} / \mathrm{ml})$ respectively with $\mathrm{p}$ value $<0.001$.

When ITP patients and control subjects were classified according to vitamin D status, 33 out of 40 ITP patients $(82.5 \%)$ had inadequate(insufficient and deficient) $25(\mathrm{OH}) \mathrm{D}$ levels $(<30 \mathrm{ng} / \mathrm{ml})$ : of which 6 patients $(15 \%)$ being insufficient $(21-29 \mathrm{ng} / \mathrm{ml}), 27(67.50 \%)$ being deficient $(\leq 20 \mathrm{ng} / \mathrm{ml})$. In contrast, 4 out of 20 healthy control subjects (20\%) were found to be insufficient, 4 (20\%) being deficient. Out of our knowledge, there was no previous studies evaluating vitamin D levels in patients with ITP in Arabian country, but there were on other autoimmune disorders 
such as SLE disease. The frequency of 25(OH) D deficiency among patients with ITP in our study is similar to that reported in a study conducted byEmam et al. ${ }^{[22]}$ on 40 SLE Egyptian patients and 20 controls which revealed low vitamin D levels in patients with SLE compared with healthy controls, and (85\%) of SLE patients had inadequate (insufficient and deficient) vitamin D levels.

Despite Egypt is a sunny country, many contributing factors lead to low vitamin D level in our population in general as in most Middle East countries, including the dark skin, use of sun screen, the cultural and religious practice of wearing clothes that cover the entire body, and the limited amount of vitamin D obtained from dietary sources due to lack of fortification and even lack of measures to confirm adequacy of fortification of fortified staple foods ${ }^{[26]}$. Also Fragoso et al. ${ }^{[27]}$ explained this to be a result from increased modern indoor life activities.

In the present study, the result is concordant to a study by Fattizzo et al. ${ }^{[28]}$ conducted on 103 patients with autoimmune cytopenias (included 44 patients with ITP, 35 with primary autoimmune hemolytic anemia, 5 with Evans' syndrome, and 19 chronic idiopathic neutropenia) and 40 controls, which revealed low $25(\mathrm{OH}) \mathrm{D}$ level in patients with ITP compared with healthy controls (mean $\pm \mathrm{SD}=2.3 \pm 1.8 \mathrm{vs} 6 \pm 6 \mathrm{ng} / \mathrm{ml}, \mathrm{P}<0.001$ ), they also found, that $25(\mathrm{OH}) \mathrm{D}$ levels were significantly lower in patients with primary autoimmune hemolytic anemia, Evans' syndrome, and chronic idiopathic neutropenia than in controls (mean $\pm \mathrm{SD}=2.4 \pm 1.6 \mathrm{ng} / \mathrm{ml}, 1.3 \pm 0.5 \mathrm{ng} / \mathrm{ml}, 2.1 \pm 1.3 \mathrm{ng} / \mathrm{ml} \mathrm{vs} 6 \pm 6 \mathrm{ng} / \mathrm{ml}, \mathrm{P}<0.001$ ).

Also, in agreement with our results a Chinese study conducted on 45 ITP patients showed that the levels of $25(\mathrm{OH}) \mathrm{D}(10.6 \pm 7.7 \mathrm{ng} / \mathrm{ml})$ and $1 \alpha, 25(\mathrm{OH}) 2 \mathrm{D}(69.9 \pm 29.0 \mathrm{pg} / \mathrm{ml})$ of the ITP patients were lower than those of healthy controls $(13.7 \pm 9.1 \mathrm{ng} / \mathrm{ml}, 87.3 \pm 19.9 \mathrm{pg} / \mathrm{ml})(\mathrm{P}<0.05)^{[29]}$.

In the present study there was no statistical difference between the ITP patients and patients with thrombocytopenia secondary to other causes (non ITP) as regard vitamin D levels. Serum $25(\mathrm{OH})$ D levels were significantly lower in patients with thrombocytopenia due to non ITP causes than normal healthy controls ( $m e a n \pm S D=21.05 \pm 8.31 \mathrm{ng} / \mathrm{ml}$ ) vs $($ mean $\pm \mathrm{SD}=36.70 \pm 16.30 \mathrm{ng} / \mathrm{ml})(\mathrm{p}<0.001)$. In fact, the patients included in this group (patients with thrombocytopenia secondary to other causes) unfortunately were patients with acute myeloid leukemias, myelodysplasticsyndrome, and aplastic anemia, and vitamin D deficiency has been implicated in the pathogenesis of these hematological and oncohematological disorders. However, many of the diseases with thrombocytopenia were associated with vitamin $\mathrm{D}$ deficiency, and we could not enroll patients with thrombocytopenia secondary to HCV or HBV because patients with liver diseases were excluded from this studyas liver disease is one of the causes of vitamin D deficiency.

In our study there was no statistically significant difference in $25(\mathrm{OH}) \mathrm{D}$ levels between responders and nonresponders (median $=15.5 \mathrm{ng} / \mathrm{ml}$ vs $19 \mathrm{ng} / \mathrm{ml}$, respectively. $\mathrm{p}=0.327$ ). This result is in concordance with the results of a study by Fattizzo et al. ${ }^{[28]}$ in which all ITP patients were treated with steroids, rituximab was administered in 1 case, cytotoxic immunosuppressives in 7, and splenectomy performed in 8; 5 cases unsuitable for or refractory to splenectomy were treated with thrombopoietin receptor agonists, and they found no significant association among the number of therapy lines and vitamin D levels. This observation may indicate that vitamin D deficiency has a role in ITP pathogenesis, but did not contribute in disease activity and treatment response. However, more studies with larger populations may be required to define the actual role of vitamin $\mathrm{D}$ in treatment response and the activity of disease in patients with ITP.

However, vitamin D was inversely correlated to disease activity in many other studies, in a study conducted byHaga et al. ${ }^{[30]}$ on 302 patients with rheumatoid arthritis, they found that very low serum $25(\mathrm{OH}) \mathrm{D}$ levels $(\leq 6 \mathrm{ng} / \mathrm{ml}) \mathrm{were}$ associated with very high disease activity and with increase the requirement of treatment with at least 3 disease modifying anti-rheumatic drugs. Furthermore, a case-control studybyRicceri et al. ${ }^{[31]}$ conducted on 68 patients with chronic plaque psoriasis and 60 healthy controls demonstrated a statistically significant inverse linear correlation between patient's vitamin D levels and their Psoriasis Area Severity Index (PASI) scores. Also Mok et al. ${ }^{[32]}$ in their study on SLE patients found that $25(\mathrm{OH})$ D level correlated inversely and significantly with SLE activity. On the other hand Ruiz-Irastorza et al. ${ }^{[33]}$ found no association between vitamin D levels and SLE disease activity. $D^{\prime}$ Aurizio et al. ${ }^{[34]}$ found that low serum levels of vitamin D did not correlate with Hashimoto's thyroiditis or with Grave's disease activity. Also, no correlation between vitamin D levels and disease activity was observed in a crosssectional study conducted by Levin et al. ${ }^{[35]}$ on children with inflammatory bowel diseases.

In the present study there was no significant correlation between vitamin D levels and platelet counts at enrollment time. Our observations are consistent with the findings of Fattizzo et al. ${ }^{[28]}$ who found no significant 
association among vitamin D levels and hemoglobin, platelets, and absolute neutrophil counts values at enrollment for AIHA, ITP and chronic idiopathic neutropenic patients, respectively. However, 20 ITP patients with very low vitamin D levels $(<1.3 \mathrm{ng} / \mathrm{ml})$ displayed reduced platelets counts compared with the remaining 24 . However, the majority of our patients were enrolled from the outpatient clinic and their platelet counts were not severely low at time of enrolment.

Despite corticosteroid use is thought to increase the catabolism of vitamin D by activating the expression of the Steroid and Xenobiotic nuclearReceptor (SXR), which induces the destruction of $25(\mathrm{OH}) \mathrm{D}$ and $1 \alpha, 25(\mathrm{OH}) 2 \mathrm{D}$ through the expression of CYP3A4 ${ }^{[36]}$. We found no correlation between use of steroids / steroid doses and vitamin D levels in our patients. Our observations are consistent with the findings of Fattizzo et al. ${ }^{[28]}$ where no relationship was found between serum 25(OH) D levels and steroid doses in ITP patients. Also, in a study conducted on SLE patients by Schoindre et al. ${ }^{[37]}$ they did not find an association between corticosteroid use or dose and vitamin D status. This finding may indicate that vitamin D deficiency in our patients was not due to steroid therapy itself. However, Toloza et al. ${ }^{[38]}$ found that cumulative corticosteroid exposure in SLE patients was associated with low vitamin D levels.

Additional support for our results, two refractory thrombocytopenic patients with concomitant lupus-like syndrome responded to hydroxychloroquine and high-dose vitamin D replacement therapy ${ }^{[39]}$. Also in a case study, 48-year-old female with refractory ITP, who was found to have an inadequate level of $25(\mathrm{OH}) \mathrm{D}$, and significantly responded to high dose vitamin $\mathrm{D}^{[4]}$

Thus, the present findings conclude that vitamin D deficiency may have an important role in the pathogenesis of primary immune thrombocytopenia and vitamin D supplementation might reduce the risk of the disease by modulating the immune system.

\section{DECLARATION OF INTEREST:-}

The authors report no conflicts of interest'

Table (1):- Comparison between the three studied groups regarding clinical characteristics:

\begin{tabular}{|c|c|c|c|c|c|c|c|c|c|}
\hline & \multirow{2}{*}{$\begin{array}{l}\text { Group I } \\
\text { ITP patients } \\
\text { No. }=40 \\
\end{array}$} & \multirow{2}{*}{$\begin{array}{l}\text { Group II } \\
\text { AML,MDS, } \\
\text { AA } \\
\text { No. }=\mathbf{2 0}\end{array}$} & \multirow{2}{*}{$\begin{array}{l}\text { Group III } \\
\text { Healthy } \\
\text { control }\end{array}$} & \multicolumn{2}{|c|}{$\begin{array}{l}\text { One Way ANOVA } \\
\text { test }\end{array}$} & \multicolumn{3}{|c|}{ Post Hoc analysis } \\
\hline & & & & & $\mathbf{F} / \mathbf{X}^{2 *}$ & P-value & P1 & $\mathbf{P 2}$ & $\mathbf{P 3}$ \\
\hline \multirow[t]{2}{*}{ Age } & Mean \pm SD & $33.41 \pm 9.67$ & $\begin{array}{ll}36.70 & \pm \\
13.30 & \\
\end{array}$ & $29.90 \pm 8.07$ & \multirow[t]{2}{*}{2.157} & \multirow[t]{2}{*}{0.123} & \multirow[t]{2}{*}{$\begin{array}{l}0.25 \\
2\end{array}$} & \multirow[t]{2}{*}{$\begin{array}{l}0.22 \\
2\end{array}$} & \multirow[t]{2}{*}{$\begin{array}{l}0.04 \\
1\end{array}$} \\
\hline & Range & $18-50$ years & $19-60$ years & $18-44$ years & & & & & \\
\hline Sex & Female & $36(90.0 \%)$ & $16(80.0 \%)$ & $17(85.0 \%)$ & 1.159 & $0.560 *$ & $\begin{array}{l}0.50 \\
2\end{array}$ & $\begin{array}{l}0.88 \\
7\end{array}$ & $\begin{array}{l}1.00 \\
0\end{array}$ \\
\hline \multirow{2}{*}{$\begin{array}{l}\text { HB } \\
(\mathrm{g} / \mathrm{dl})\end{array}$} & Mean \pm SD & $11.31 \pm 1.48$ & $7.80 \pm 1.03$ & $12.66 \pm 1.37$ & \multirow{2}{*}{71.051} & \multirow{2}{*}{0.000} & \multirow{2}{*}{$\begin{array}{l}0.00 \\
0\end{array}$} & \multirow{2}{*}{$\begin{array}{l}0.00 \\
1\end{array}$} & \multirow{2}{*}{$\begin{array}{l}0.00 \\
0\end{array}$} \\
\hline & Range & $8.8-15$ & $5.5-9.6$ & $10.5-15.8$ & & & & & \\
\hline \multirow{2}{*}{$\begin{array}{l}\text { PLT } \\
\text { (x10 } / \\
\text { l) }\end{array}$} & $\begin{array}{l}\text { Median } \\
\text { (IQR) }\end{array}$ & $\begin{array}{l}114 \quad(64 \\
200.5)\end{array}$ & $\begin{array}{lll}36.5 & (19 & - \\
56.5) & & \end{array}$ & $\begin{array}{l}296 \quad(230- \\
318.5)\end{array}$ & \multirow[t]{2}{*}{44.968} & \multirow[t]{2}{*}{$0.000^{\bullet}$} & \multirow[t]{2}{*}{$\begin{array}{l}0.00 \\
0\end{array}$} & \multirow[t]{2}{*}{$\begin{array}{l}0.00 \\
0\end{array}$} & \multirow[t]{2}{*}{$\begin{array}{l}0.00 \\
0\end{array}$} \\
\hline & Range & $15-352$ & $2-98$ & $176-442$ & & & & & \\
\hline $\begin{array}{l}\text { MPV } \\
\text { (fl) }\end{array}$ & $\begin{array}{l}\text { Mean } \pm \text { SD } \\
\text { Range }\end{array}$ & $\begin{array}{l}11.16 \pm 2.14 \\
6.8-19.1\end{array}$ & $\frac{9.10 \pm 3.40}{0-14.3}$ & $\begin{array}{l}9.79 \pm 1.01 \\
8.1-11.5\end{array}$ & 5.846 & 0.004 & $\begin{array}{l}0.00 \\
2\end{array}$ & $\begin{array}{l}0.03 \\
5\end{array}$ & $\begin{array}{l}0.35 \\
2\end{array}$ \\
\hline
\end{tabular}

*: Chi-square test.

$\because$ Kruskal-Wallis.

P1: Group I vs Group II.

P2: Group I vs control group.

P3: Croup II vs control group.

(MPV=mean platelet volume). 


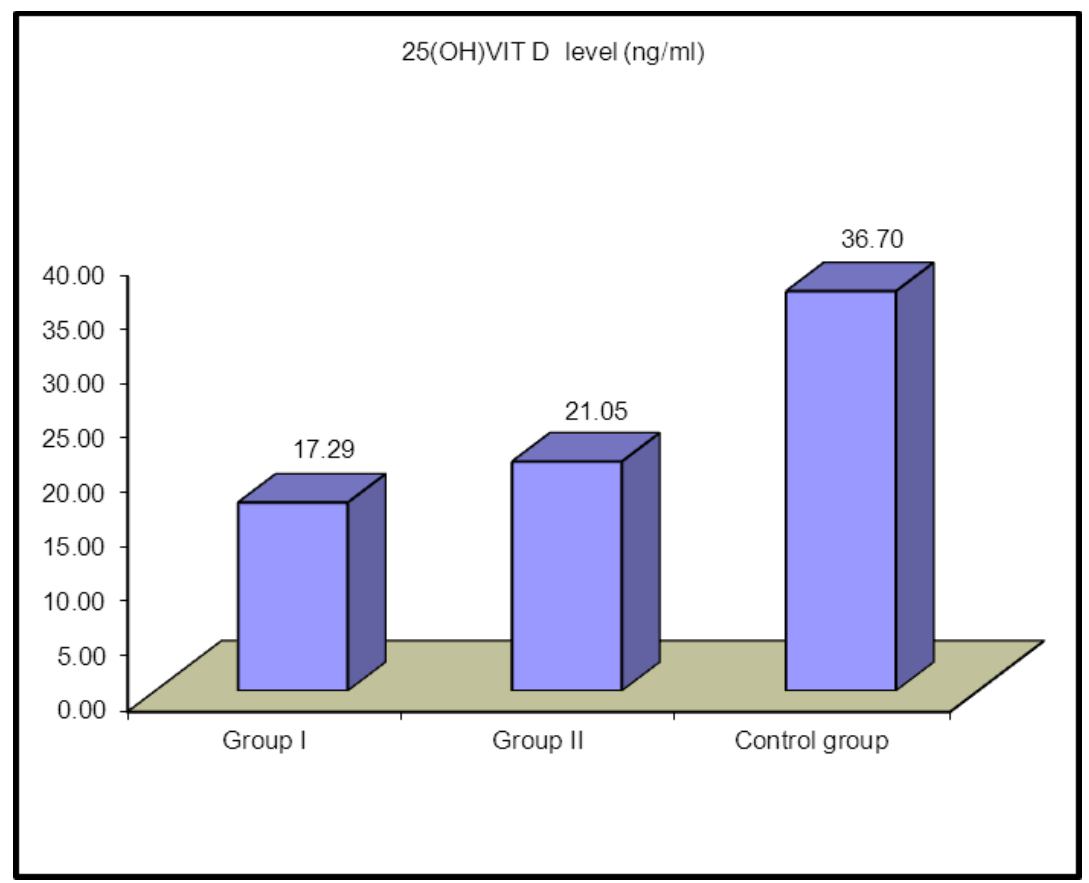

Figure (1):-Showing that 25(OH) D levels were significantly lower in ITP patients and patients with thrombocytopenia due to other causes than healthy control $(\mathrm{p}=0.000)$.

\section{REFERENCES:-}

1. Neunert C, Lim W, Crowther M, et al. (2011): American Society of Hematology evidence-based practice guidelines for immune thrombocytopenia. Blood; 117: 4190-207.

2. Stasi R (2012): Immune Thrombocytopenia: Pathophysiologic and Clinical Update. SeminThrombHemost; 38 : 454-62.

3. DeLuca HF (2004): Overview of general physiologic features and functions of vitamin D. Am. J. Clin. Nutr; 80:1689S-96S.

4. Schwalfenberg G K. (2012): Solar Radiation and Vitamin D: Mitigating Environmental Factors in Autoimmune Disease. Journal of Environmental and Public Health; 2012: 1-9.

5. Agmon-Levin N, Theodor E, Segal RM, et al. (2013): Vitamin D in Systemic and Organ-Specific Autoimmune Diseases. Clinic Rev AllergImmunol; 45: 256-66.

6. Antico A, Tozzoli R, Giavarina D, et al. (2012): Hypovitaminosis D as predisposing factor for atrophic type A gastritis: a case-control study and review of the literature on the interaction vitamin D with the immune system. Clin Rev Allergy Immunol;42:355-64.

7. Provan D, Stasi R, Newland AC, et al. (2010): International consensus report on the investigation and management of primary immune thrombocytopenic. Blood; 115:168-86.

8. Holick MF, Binkley NC, Bischoff-Ferrari HA, et al. (2011): Evaluation, treatment, and prevention of vitamin D deficiency: an Endocrine Society clinical practice guideline. J ClinEndocrinolMetab.; 96: 1911-30.

9. McMillan R(2007): The pathogenesis of chronic immune thrombocytopenic purpura. SeminHematol.; 44:S311.

10. Gatenby P, Lucas R and Swaminathan A (2013): Vitamin D deficiency and risk forrheumatic diseases: an update. CurrOpinRheumatol.;25: 184-91.

11. Schoonen WM, Kucera G, Coalson J, et al. (2009): Epidemiology of immune thrombocytopenic purpura in the general practice research database. Br J Haematol; 145: 235-44.

12. Saeidi S, Jaseb K, Asnafi A, et al. (2014): Immune Thrombocytopenic Purpura in Children and Adults: A Comparative Retrospective Study in IRAN. International Journal of Hematology-Oncology and Stem Cell Research; 8: 30-36.

13. Cines DB and Bussel JB (2005): How I treat thrombocytopenic purpura (ITP). Blood; 106: 2244-51.

14. Neylon N, Saunders G, Howard R, et al. (2003): Clinically significant newly diagnosed presenting autoimmune thrombocytopenic pupura in adults: a prospective study of a population-based cohort of 245 patients. British Journal of Haematology; 122: 966-74. 
15. Ntaios G, Papadopoulos A, Chatzinikolaou A, et al. (2008): Increased values of mean platelet volume and platelet size deviation width may provide a safe positive diagnosis of idiopathic thrombocytopenic purpura. ActaHaematologica.; 119: 173-77.

16. Negash M, Tsegaye A and MedhinA(2016): Diagnostic predictive value of platelet indices for discriminating hypo productive versus immune thrombocytopenia purpura. BMC Hematology; 16: 1-8.

17. Borkataky S, Jain $\mathbf{R}$ and Gupta $\mathbf{R}$ (2013): Role of platelet volume indices in the differential diagnosis of thrombocytopenia: a simple and inexpensive method. Hematoloy; 14: 182-86.

18. Colkesen $Y$ and Muderrisoglu $H$ (2012): The role of mean platelet volume in predicting thrombotic events.ClinChem Lab Med.; 50: 631-34.

19. Elsammak MY, Al-Wossaibi AA, Al-Howeish A, et al. (2011): High prevalence of vitamin D deficiency in the sunny Eastern region of Saudi Arabia: a hospital-based study. East Mediterr Health J.; 17: $317-22$.

20. Amital H, Szekanecz Z, Szücs G, et al. (2010): Serum concentrations of 25-OH vitamin D in patients with systemic lupus erythematosus (SLE) are inversely related to disease activity: is it time to routinely supplement patients with SLE with vitamin D? Ann Rheum Dis.; 69: 1155-57.

21. Wright TB, Shults J, Leonard MB, et al. (2009): Hypovitaminosis D is Associated with Greater Body Mass Index and Disease Activity in Pediatric Systemic Lupus Erythematosus.JPediatr.; 52: 1333-40.

22. Emam FE, Abd El-Wahab TM, Mohammed MS, et al. (2014): Assessment of serum vitamin D level in patients with systemic lupus erythematosus. Egyptian Rheumatology and Rehabilitation; 41: 71-78.

23. Rossini M, Bongi MS, LaMontagna G, et al. (2010): Vitamin D deficiency in rheumatoid arthritis: prevalence, determinants and associations with disease activity and disability. Arthritis Res. Ther; 12: R216.

24. Dias de Castro F, Magalhães J, BoalCarvalho P, et al. (2015): Lower levels of vitamin D correlate with clinical disease activity and quality of life in inflammatory bowel disease. ArqGastroenterol; 52: $260-65$.

25. Karatay S, Yildirim K, Karakuzu A, et al. (2011): Vitamin D status in patients with Behcet's Disease. CLINICS; 66: 721-23.

26. Damanhouri LH (2009): Vitamin D Deficiency in Saudi Patients with Systemic Lupus Erythematosus. Saudi Med J.; 30: 1291- 95.

27. Fragoso TS, Dantas AT, Marques CD et al. (2012): 25-Hydroxyivitamin D3 levels in patients with systemic lupus erythematosus and its association with clinical parameters and laboratory tests. Rev Bras Reumatol; 52: 60-65.

28. Fattizzo B, Zaninoni A, Giannotta JA, et al. (2016): Reduced 25-OH vitamin D in patients with autoimmune cytopenias,clinical correlations and literature review. Autoimmunity Reviews; 15: 770-75.

29. Mu W, Wang W, Cui ZG, et al. (2013): Expression and significance of vitamin D and its receptor mRNA in the peripheral blood of initial immune thrombocytopenic patients. Journal of experimental hematology;21:684-87.

30. Haga HJ, Schmedes A, Naderi Y, et al. (2013): Severe deficiency of 25-hydroxyvitamin D3 is associated with high disease activity of rheumatoid arthritis. ClinRheumatol.; 32: 629-33.

31. Ricceri F, Pescitelli L, Tripo L, et al. (2013): Deficiency of serum concentration of 25-hydroxyvitamin D correlates with severity of disease in chronic plaque psoriasis. J Am AcadDermatol; 68: 511-12.

32. Mok CC, Birmingham DJ, Leung HW, et al. (2012): Vitamin D levels in Chinese patients with systemic lupus erythematosus: relationship with disease activity, vascular risk factors and atherosclerosis.Rheumatology; 51: 644-52.

33. Ruiz-Irastorza G, Gordo S, Olivares N, et al.(2010): Changes in vitamin D levels in patients with systemic lupus erythematosus: Effects on fatigue, disease activity, and damage. Arthritis Care Res (Hoboken); 62: 116065.

34. D'Aurizio F, Villalta D, Metus P, et al. (2015): Is vitamin D a player or not in the pathophysiology of autoimmune thyroid diseases? Autoimmun Rev; 14: 363-69.

35. Levin AD, Wadhera V, Leach ST, et al. (2011):Vitamin D deficiency in children with inflammatory bowel disease Dig Dis Sci.; 56: 830-36.

36. Holick MF.(2007): Vitamin D deficiency. New Engl J Med; 357:266-81.

37. SchoindreY,Jallouli M, Tanguy ML et al. (2014): Lower vitamin D levels are associated with higher systemic lupus erythematosus activity, but not predictive ofdisease flare-up. LupusScience\& Medicine.; 1: e000027.

38. Toloza S, Cole D and Gladman D (2010): Vitamin D insufficiency in a large female SLE cohort. Lupus.; 19: 13-19.

39. Bockow B and Kaplan TB, (2013): Refractory immune thrombocytopenia successfully treated with high-dose vitamin D supplementation and hydroxychloroquine: two case reports. Journal of Medical Case Reports; $7: 91$. 